\title{
Reply to the Discussion of "IFRS Adoption, Extent of Disclosure, and Perceived Corruption: A Cross-Country Study”
}

\author{
Muhammad Nurul Houqe, Reza M. Monem ${ }^{1}$
}

\section{Introduction}

The discussant, Professor Asheq R. Rahman (AR), raised six issues: focus and contribution, theory and hypotheses, sample selection, selection and measurement of variables, endogeneity problems, and the scope of inferences derived from this study. In this reply, we provide clarifications addressing AR’s concerns.

\subsection{Focus and contribution}

A major finding of our study is that relative to developed countries, developing countries benefit more from IFRS experience in lowering perceived corruption. AR suggested that we provide a "more befitting title for the paper to reflect the importance of IFRS adoption in developing countries." Given that the vast majority of countries in the world are developing countries, empirical evidence provided in our paper mostly refers to developing countries. Besides, in our sample of 104 countries, most are developing countries with high perceived corruption. However, we chose the title to reflect a general negative association between the experience of IFRS adoption and perceived corruption. We believe we paid adequate attention to developing countries by presenting the relevant analysis in a separate sub-section.

\subsection{Theory and hypotheses}

AR questioned the appropriateness of tying a country-level variable (perceived corruption) with corporate-level variables (length of IFRS experience and the extent of disclosure). Although

\footnotetext{
${ }^{1}$ Corresponding author:

Email address: r.monem@griffith.edu.au
} 
MS-14-06-573 Response to Discussion

$3 / 28 / 16$

IFRS are employed at the firm level for financial reporting, we measured IFRS experience at the country level (i.e., the number of years since a country has mandatorily adopted the IFRS). As explained in Section 4.1 of the paper, we measured "extent of disclosure” as the World Bank's measure of how well minority shareholders are protected through disclosure against self-dealing in related-party transactions. Thus, both of the measures are country-level measures, and AR's assertion is not correct.

AR also raised the possibility of a reverse causality that countries with lower perceived corruption may encourage better corporate governance practice such as adopting IFRS. We can rule out this possibility on two grounds: (1) The overwhelming evidence in the corruption literature is that the level of economic development is inversely related to both actual corruption and perceived corruption (Serra, 2006; Treisman, 2007), and (2) the vast majority of the countries that have mandatorily adopted the IFRS are developing countries. Besides, most of the countries in our sample are developing countries with high perceived corruption.

AR used the example of Singapore and Malaysia as countries that improved their accounting and disclosure practices despite lower perceived corruption following the Asian Financial Crisis of 1997. We do not claim that perceived corruption is the only motivation for improving financial reporting and disclosure, but rather, improvement in financial reporting and disclosure practices can indeed lower perceived corruption.

\subsection{Sample selection}

AR questioned the exclusion of countries such as Indonesia, Malaysia, Thailand, USA, and Japan from the sample. These countries did not adopt IFRS during the period covered in this study. 
MS-14-06-573 Response to Discussion

$3 / 28 / 16$

\section{Indonesia:}

Indonesia has not adopted IFRS.

\section{Malaysia}

In August 2008, the Malaysian Accounting Standards Board (MASB) announced its plan to converge with IFRS in 2012. In November 2011, the MASB issued the Malaysian Financial Reporting Standards (MFRS), which were in agreement with all IFRS in effect as of 1 January 2012 (IFRS Foundation, 2015). Thus, Malaysia did not adopt IFRS within our sample period (2009-2011).

\section{Thailand:}

Thailand is in process of adopting IFRS as Thai Financial Reporting Standards (TFRS). As of 1 January 2014, TFRS were a word-for-word adoption of IFRS, with the exception of the industryspecific standards IFRS 4, Insurance Contracts, and IAS 41, Agriculture, and the financial instruments standards IAS 32; Financial Instruments: Presentation; IAS 39, Financial Instruments: Recognition and Measurement; IFRS 7, Financial Instruments: Disclosures; and IFRS 9, Financial Instruments. One of the reasons that the adoption of IFRS is delayed in Thailand is the need to translate the standards into the Thai language.

\section{USA \& Japan:}

USA and Japan have not adopted IFRS.

Thus, none of the countries listed by AR adopted IFRS during our study period.

\subsection{Variable selection procedure}

AR also commented that the threshold for low economic development in footnote 10 is not clear. The World Bank classifies all countries into four income groups: (1) low income, (2) lower middle income, (3) upper middle income, and (4) high income. Income thresholds for such 
MS-14-06-573 Response to Discussion

$3 / 28 / 16$

classification are set on July 1 of every year. The World Bank classifies all low-and middleincome countries as developing countries (see the World Bank website for detailed discussion). Along the same spirit, we classified all low and lower-middle income countries as developing countries. The upper limit for lower-middle income countries in 2009, 2010, and 2011 was US\$4,528, US\$4,887, and US\$5,203, respectively.

AR raised a concern regarding the aggregated variable measures of accounting environment and political institutions. This study closely followed the methodology of Cai, Rahman, and Courtenay (2014), Daske, Hail, Leuz, and Verdi (2008), DeFond, Hu, Hung, and Li (2011), and Houqe, Monem, \& van Zijl (2012).

\subsection{Endogeneity}

Unlike prior studies in this area (e.g., DiRienzo, Das, Cort, \& Burbridge, 2007; Kimbro, 2002; Malagueño, Albrecht, Ainge, \& Stephens, 2010), we controlled for endogeneity using 2SLS. AR again raised the possibility of reverse causality while discussing the issue of endogeneity. He also suggested that less corrupt countries may have simply adopted IFRS. The overwhelming evidence in the data is just the contrary (see Appendix 1 in the paper). In the world, the vast majority of the countries are developing countries. Of the 131 jurisdictions that require or permit IFRS for domestic listed companies (as per IASPlus website), the vast majority are developing countries. So is the case in our sample. Thus, the possibility of a reverse causality is contradictory to the empirical regularity observed in the data.

\subsection{Inferences}

We agree with AR that examining the association between corruption and accounting environmental variables is a very complex matter. Hence, we undertook a battery of robustness 
MS-14-06-573 Response to Discussion

$3 / 28 / 16$

tests (see Section 6 in the paper), including controlling for endogeneity, type of political system, taxation regime, investor protection, and differences in cultural values across countries.

\subsection{Conclusion}

We thank AR for a balanced discussion of our paper. While AR appreciated our efforts in exploring the relationship between IFRS adoption and perceived corruption, we are fully aware of the challenges in this endeavour. Nevertheless, we documented a new benefit of IFRS adoption that has not been documented in the literature so far. We hope our study will encourage future research in exploring further how changes in the accounting environment can influence societal values.

\section{Acknowledgements}

We appreciate the discussion and comments provided by Professor Asheq R. Rahman. We acknowledge helpful comments from the 2013 Illinois International Accounting Symposium held in Wuhan, China. We also thank the three anonymous reviewers of The International Journal of Accounting and the editor, A. Rashad Abdel-Khalik, for many constructive suggestions. 
MS-14-06-573 Response to Discussion

$3 / 28 / 16$

\section{References}

Cai, L., Rahman, A., \& Courtenay, S. (2014). The effect of IFRS adoption conditional upon the level of pre-adoption divergence. The International Journal of Accounting, 49(2), 147178.

Daske, H., Hail, L., Leuz, C., \& Verdi, A. (2008). Mandatory IFRS reporting around the world: Early evidence on the economic consequences. Journal of Accounting Research, 46(5), 1085-1142.

DeFond, M., Hu, X., Hung, M., \& Li, S. (2011). The impact of mandatory IFRS adoption on foreign mutual fund ownership: The role of comparability. Journal of Accounting \& Economics, 51, 240-258.

DiRienzo, E., Das, J., Cort, K. T., \& Burbridge, J. (2007). Corruption and the role of information. Journal of International Business Studies, 38(2), 320-332.

Houqe, M., \& Monem, R. (2016). IFRS adoption, extent of disclosure, and perceived corruption: A cross-country study. The International Journal of Accounting (Forthcoming).

Houqe, M, N., Monem, R., \& van Zijl, T. (2012). Government quality, auditor choice and adoption of IFRS: A cross country analysis. Advances in Accounting incorporating Advances in International Accounting, 28(2), 307-316.

IFRS Foundation. (2015). IFRS application around the world, jurisdictional profile: Malaysia. Available at IFRS Foundation website (http://www.ifrs.org).

Kimbro, M. B. (2002). A cross-country empirical investigation of corruption and its relation to economic, cultural, and monitoring institutions: An examination of the role of accounting and financial statements quality. Journal of Accounting Auditing and Finance, 17(4), 325-75.

Malagueño, R., Albrecht, C., Ainge, C., \& Stephens, N. (2010). Accounting and corruption: A cross-country analysis. Journal of Money Laundering Control, 13(4), 372-393.

Serra, D. (2006). Empirical determinants of corruption: A sensitivity analysis. Public Choice, 126(1), 225-256.

Treisman, D. (2007). What have we learned about the causes of corruption from ten years of cross-national empirical research? Annual Review of Political Science, 10, 211-244. 